\title{
Synthesis of some new 6-aryl-3-(4-isopropylphenyl)[1,2,4]triazolo[3,4-b][1,3,4] thiadiazoles and its anti-microbial study
}

\author{
K. A. Joshi ${ }^{\text {, J. M. Dhalani }}{ }^{\text {, H. B. Bhatt }}{ }^{\mathrm{c}}$ and K. M. Kapadiya $\mathrm{b}^{\mathrm{b}^{*}}$
}

${ }^{a}$ Shree D K V Arts \& Science College, Jamnagar-361008, Gujarat, India

${ }^{b}$ Department of Chemistry, School of Science, RK University, Rajkot-360020, Gujarat, India

'Department of Chemistry, Om College of Science \& P G Center, BKNMU, Junagadh-362310, Gujarat, India

\section{H R O N I C L E}

\begin{tabular}{l}
\hline Article history: \\
Received December 16, 2020 \\
Received in revised form \\
April 2, 2021 \\
Accepted April 12, 2021 \\
Available online \\
April 14, 2021 \\
\hline Keywords: \\
1,2,4-Triazole \\
1,3,4-Thiadiazole \\
Triazolo-thiadiazole \\
Antimicrobial activity \\
\end{tabular}

\section{A B S T R A C T}

\begin{abstract}
New series of fused 1,2,4-triazoles, i.e., 3-(4-isopropylphenyl)-6-substituted phenyl$[1,2,4]$ triazolo[3,4- $b][1,3,4]$ thiadiazoles $(\mathbf{5} \mathbf{a}-\mathbf{5} \mathbf{j})$ have been synthesized via a four-step procedure and using eco-friendly reaction condition at some steps of the synthesis. It was adopted by the formation of hydrazide of methyl 4-isopropylbenzoate (1) followed by reaction with $\mathrm{CS}_{2}$ in basic media to afford potassium salt, which on cyclized to our essential step, 4-amino-5-(4isopropylphenyl)-4H-1,2,4-triazole-3-thiol (4). The desired adducts (5a-5j) were formed by (4) on reaction with various aromatic acids in $\mathrm{POCl}_{3}$ media. The newly synthesized triazolothiadiazoles have been characterized by different spectroscopic techniques and investigated for their in vitro antibacterial and antifungal activity. It was revealed that the compounds $\mathbf{5 a}, \mathbf{5 c}, \mathbf{5 h}$, and $\mathbf{5 i}$ showed interesting antibacterial and antifungal activity compared to the used reference standard.
\end{abstract}

\section{Introduction}

The structural diversity associated with various nitrogen, oxygen, and sulfur-containing heterocycles has been proved to be efficient medicinal candidates to cure/inhibit the disease based on computational designing tools ${ }^{1-3}$. Besides, nature is the bunch of such motifs like in biomolecules such as enzymes, vitamins, terpenoids, alkaloids, etc ${ }^{4}$. The availability of various reactive sites in the triazole or thiadiazole ring systems is acting as lead motifs in the therapeutic investigations ${ }^{5-7}$. It is well-known that anti-microbial resistance is a new challenge for chemists besides diverse antibiotics and medicinally active anti-microbial agents ${ }^{8-11}$. Some of the synthetic aspects and functional scaffolds such as 1,3,4-oxadiazole, 1,3,4-thiadiazole, and 1,2,4-triazoles have been identified to exhibit a wide range of biological activities viz. anti-microbial and antimycobacterial ${ }^{12-16}$. According to these studies, 1,2,4-thiadiazole is the bioisostere of pyrimidine. The bioisosteric replacement of a ring with another ring might lead to compounds with increased lipophilicity and improved biological properties ${ }^{17-19}$. Due

* Corresponding author. Tel.: +91 9586980779

E-mail address: Khushal kapadiya06@yahoo.com (K. M. Kapadiya)

(C) 2021 Growing Science Ltd. All rights reserved. doi: $10.5267 /$ j.ccl.2021.4.003 
to the presence of sulfur atom that gives high liposolubility, the thiadiazole derivatives show oral absorption and good cell permeability, leading to a good bioavailability ${ }^{20}$. In medicinal fields, triazole is regarded as a structurally active (bioisostere of imidazole) molecule but proved to possess advantages over the other five-membered heterocycles and found to incorporate in various triazole based drug molecules such as posaconazole, fluconazole, itraconazole, and many others ${ }^{21,22}$. Patents filed in recent, new triazole and thiadiazole ring comprising products are beneficial for emerging innovative drug molecules ${ }^{23}$. The current literature survey revealed that 1,2,4-triazolo[3,4- $\left.b\right]$ thiadiazine derivatives had been found to possess promising biological activities such as antimicrobial ${ }^{24}$, antiiflammatory $^{25}$, antiviral ${ }^{26}$, anthelmintic ${ }^{27}$, anti-cancer/antitumor ${ }^{28,}$ and many more ${ }^{29}$.

Prompted by these observations and in continuation of our search for alternate medicinal active compounds ${ }^{30,31}$, we synthesized and evaluated a series of distinct 3-(4-isopropylphenyl)-6-substituted phenyl-[1,2,4]triazolo[3,4-b][1,3,4]thiadiazoles derivatives as potential anti-microbial agents. We highlighted the approach of blending two chemically distinct but pharmacologically harmonizing molecules (the 1,2,4-triazole and 1,3,4 thiadiazole) in a single framework to check their biocompatibility against some anti-microbial strains.

\section{Result and discussion}

\subsection{Chemistry and Spectroscopic discussion}

The target compounds were synthesized as outlined in Reaction Scheme 1. The title compound, 3(4-isopropylphenyl)-6-substituted phenyl-[1,2,4]triazolo[3,4-b][1,3,4] thiadiazole (5a-5j) were synthesized by a four-step procedure starting from hydrazide of ester (1). Treatment of hydrazide (2) with carbon disulfide, in the presence of potassium hydroxide, afforded the potassium salt of hydrazinecarbodithioate 3. Furthermore, treatment of the salt 3 with hydrazine hydrate in aqueous methanol afforded the corresponding 1,2,4-triazole $\mathbf{4}$. Compound 4 with substituted aromatic acid in heating with neat phosphorous oxychloride afforded final adducts 5a-5j. The compounds of the series were identified by spectral data. In the IR spectra all intermediate steps were identified by disappearing one or more signals viz. absence of carbonyl frequency and appearance of -S-H signal in product $\mathbf{4}$. The $\mathrm{C}=\mathrm{N}$ and $\mathrm{N}-\mathrm{N}$ bands were observed in the final compounds at $1590 \mathrm{~cm}^{-1}$ and $1015 \mathrm{~cm}^{-1}$. In the ${ }^{1} \mathrm{H}$ NMR spectra of the compounds, which were taken in DMSO-d6. In the intermediate compound 4, $\mathrm{NH}_{2}$ protons were found singlet at $3.45 \mathrm{ppm}$ and $-\mathrm{SH}$ proton at $3.35 \mathrm{ppm}$. The isopropyl group (2- $\mathrm{CH}_{3}$ $\&>\mathrm{CH}-$ ) in all compounds appeared as doublets at $1.13 \mathrm{ppm}$ and multiplet at $3.05 \mathrm{ppm}$, which confirms the isopropyl group thought processes. The aromatic protons appear as a multiplet at about 7.05$8.20 \mathrm{ppm}$. The compounds' mass spectra showed molecular ion peaks $[\mathrm{M}]^{+}$, in agreement with their molecular formula. In the ${ }^{13} \mathrm{C}$ NMR spectra of all compounds $\mathbf{5 a - 5 j}$, the triazolo-thiadiazole carbons' peaks appeared at 140-160 ppm. All other aromatic and aliphatic carbons (Isopropyl groups' carbons) were observed at expected regions. All compounds gave satisfactory elemental analysis.

The in vitro antibacterial activity of $\mathbf{5 a - 5 j}$ was tested against Staphylococcus aureus, Bacillus subtilis (e.g., Gram-positive bacteria), and Escherichia coli, Salmonella paratyphi B (e.g., for Gramnegative bacteria). Antifungal activity was reported using Aspergillus niger and Candida albicans, fungi strains. The Mueller Hinton Agar plates ${ }^{32-34}$ determined the minimum inhibitory concentration (MIC, $\mu \mathrm{g} / \mathrm{ml}$, i.e., the lowest concentration required to inhibit the growth of bacteria) of all the compounds; subculturing was carried out on Nutrient Agar plates. For comparison, Ciprofloxacin was used for antibacterial screening and fluconazole for antifungal screening as a reference drug (Table 1). 


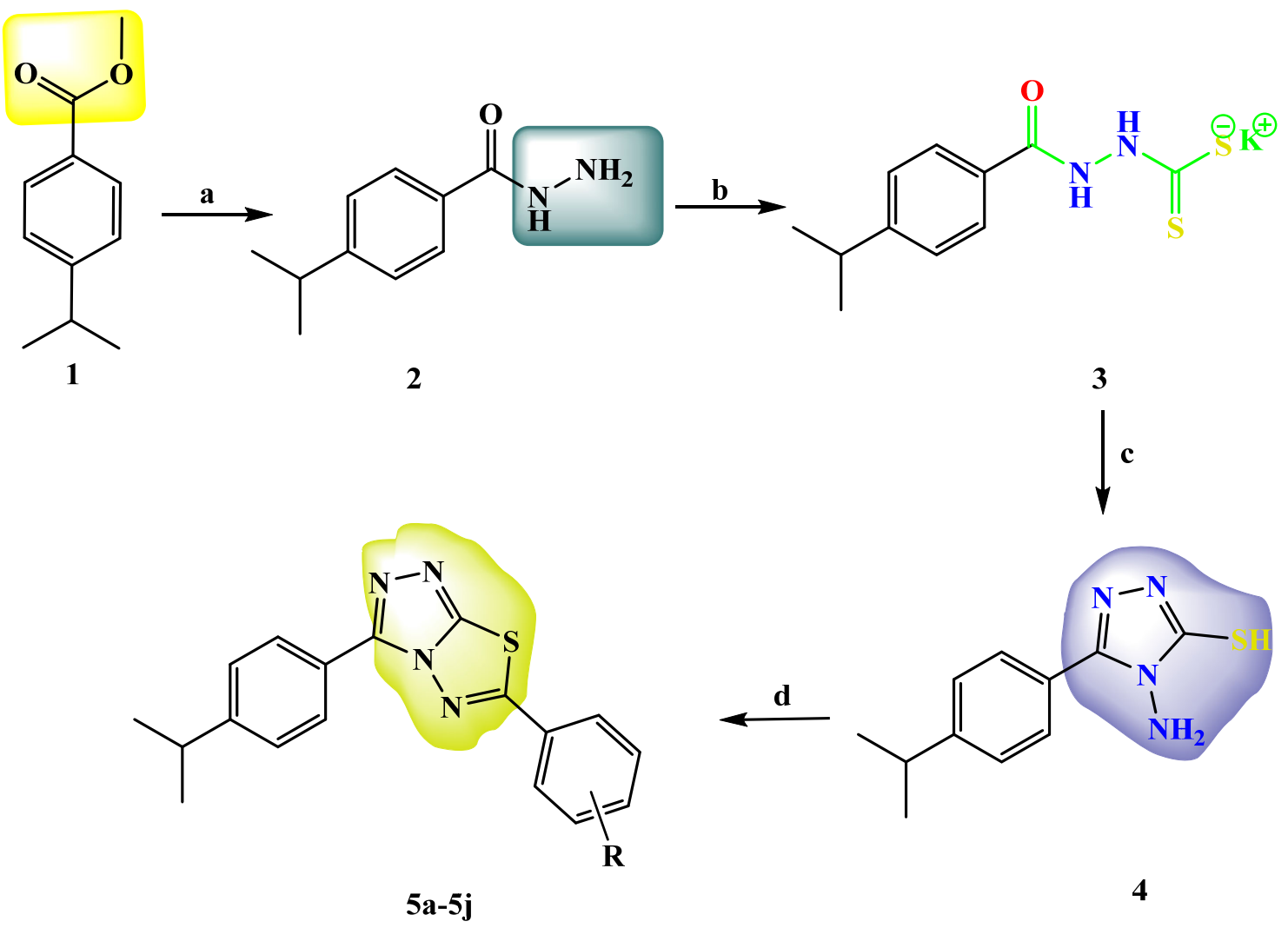

Reaction Conditions: a) Hydrazine hydrate, Methanol, $70{ }^{\circ} \mathrm{C}, 2 \mathrm{~h}$. b) $\mathrm{CS}_{2}, \mathrm{KOH}$, Methanol, RT, $12 \mathrm{~h}$. c) Hydrazine hydrate, Methanol, $70^{\circ} \mathrm{C}, 3 \mathrm{~h}$. d) Aromatic Acid, $\mathrm{POCl}_{3}, 80^{\circ} \mathrm{C}, 10 \mathrm{~h}$.

\begin{tabular}{|clll}
$\mathbf{R}=5 \mathrm{a}=4-\mathrm{OCH}_{3}$ & $5 \mathrm{~b}=2,4-\mathrm{di}-\mathrm{OH}$ & $5 \mathrm{c}=2-\mathrm{CH}_{3}$ & $5 d=3-\mathrm{OPh}$ \\
$5 \mathrm{e}=4-\mathrm{Br}$ & $5 \mathrm{f}=4-\mathrm{Cl}$ & $5 \mathrm{~g}=4-\mathrm{NO}_{2}$ & $5 \mathrm{~h}=3-\mathrm{NO}_{2}$ \\
& & & \\
$5 \mathrm{i}=2-\mathrm{OH}$ & $5 \mathrm{j}=2-\mathrm{Cl}$ & & \\
\hline
\end{tabular}

Scheme 1. Synthetic outline for the generation of $[1,2,4]$ triazolo $[3,4 b][1,3,4]$ thiadiazole $(\mathbf{5 a}-\mathbf{5 j} \mathbf{)}$ 
Table 1. Results of the antibacterial and anti-microbial activity of synthesized compounds (5a-5j)

\begin{tabular}{|c|c|c|c|c|c|c|c|c|c|c|c|c|c|c|c|c|c|c|c|}
\hline \multirow[t]{4}{*}{ Sr. No. } & \multirow{4}{*}{ 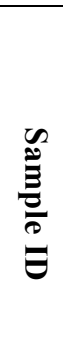 } & \multicolumn{12}{|c|}{ Antibacterial activity $(\mu \mathrm{g} / \mathrm{ml})$} & \multirow{2}{*}{\multicolumn{6}{|c|}{$\begin{array}{c}\text { Antifungal activity ( } \mu \mathrm{g} / \mathrm{ml}) \\
\begin{array}{c}\text { Uni/Multicellular Fungi } \\
\text { strains }\end{array} \\
\end{array}$}} \\
\hline & & \multicolumn{6}{|c|}{ Gram-positive strains } & \multicolumn{6}{|c|}{ Gram-negative strains } & & & & & & \\
\hline & & \multicolumn{3}{|c|}{ S. Aureus } & \multicolumn{3}{|c|}{ B. subtilis } & \multicolumn{3}{|c|}{ E. coli } & \multicolumn{3}{|c|}{ Paratyphi B } & \multicolumn{3}{|c|}{ A. Niger } & \multicolumn{3}{|c|}{ C. Albicans } \\
\hline & & ஓ̊ & ᄋ & \& & ஓ & § & 을 & ஓ & $\stackrel{8}{\circ}$ & $\stackrel{8}{8}$ & ஓ̊ & § & \& & ஓ্ণ & ᄋ & \& & ஓ & $\stackrel{8}{8}$ & \& \\
\hline 1. & $5 \mathbf{a}$ & + & + & - & + & + & + & + & + & - & + & + & - & + & + & + & + & + & - \\
\hline 2. & $5 \mathbf{b}$ & + & + & - & + & + & + & - & - & - & + & + & - & + & + & + & - & - & - \\
\hline 3. & $5 c$ & + & + & + & + & + & + & + & + & + & + & + & + & + & + & - & + & + & - \\
\hline 4. & $5 d$ & + & + & - & + & + & - & + & + & - & + & + & - & + & + & - & + & + & - \\
\hline 5. & $5 e$ & - & - & - & + & + & - & + & + & - & + & + & - & - & - & - & - & - & - \\
\hline 6. & 5f & - & - & - & + & + & - & + & + & - & + & + & - & - & - & - & - & - & - \\
\hline 7. & $5 \mathrm{~g}$ & + & + & - & + & + & + & - & - & - & + & + & - & + & + & + & - & - & - \\
\hline 8. & $5 \mathrm{~h}$ & + & + & + & + & + & + & + & + & + & + & + & + & + & + & - & + & + & - \\
\hline 9. & $5 i$ & + & + & + & + & + & + & + & + & + & + & + & - & + & + & - & - & - & - \\
\hline 10. & $5 \mathbf{j}$ & + & + & - & + & + & + & - & - & - & - & - & - & + & + & - & + & + & - \\
\hline \multicolumn{2}{|c|}{ Ciprofloxacin } & \multicolumn{3}{|c|}{1.9} & \multicolumn{3}{|c|}{7.8} & \multicolumn{3}{|c|}{0.4} & \multicolumn{3}{|c|}{1.4} & \multicolumn{3}{|c|}{-} & \multicolumn{3}{|c|}{-} \\
\hline \multicolumn{2}{|c|}{ Fluconazole } & \multicolumn{3}{|c|}{-} & \multicolumn{3}{|c|}{-} & \multicolumn{3}{|c|}{-} & \multicolumn{3}{|c|}{-} & \multicolumn{3}{|c|}{0.7} & \multicolumn{3}{|c|}{0.4} \\
\hline
\end{tabular}

The compounds $\mathbf{5 a}\left(4-\mathrm{OCH}_{3}\right), \mathbf{5 c}\left(2-\mathrm{CH}_{3}\right), \mathbf{5 h}\left(3-\mathrm{NO}_{2}\right)$, and $\mathbf{5 i}(2-\mathrm{OH})$ show comparable activity against used bacterial strains. The compounds 5a showed the best antibacterial activity against gram Ve bacteria Escherichia coli and salmonella paratyphi $B$ and was found to be as potent as a reference drug in gram +Ve bacteria, i.e., Staphylococcus aureus and Bacillus subtilis. The obtained results revealed that anti-microbial activity of the newly synthesized heterocyclic compounds, 5a-5j containing 1,2,4-triazole moiety fused with 1,3,4-thiadiazole ring depend on the basic skeleton of the molecule instead of the substituents, and all were found moderately helpful as compared to the reference drug. Meanwhile, among triazolothiadiazine derivatives, it was noticed that the activity depends on the substituents rather than the basic skeleton of the molecule. Overall, it was found that donating part in the aromatic system influences the synthesized molecules' potency.

\section{Conclusions}

In summary, a series of $[1,2,4]$ triazolo[3,4- $b][1,3,4]$ thiadiazole derivatives $\mathbf{( 5 a - 5 j )}$ were synthesized and evaluated as anti-microbial agents against a group of antibacterial and antifungal strains. They were found to possess reasonably good antifungal activity, and compounds $\mathbf{5 a}\left(4-\mathrm{OCH}_{3}\right), \mathbf{5 c}\left(2-\mathrm{CH}_{3}\right), \mathbf{5 h}(3-$ $\left.\mathrm{NO}_{2}\right), \mathbf{5 i}(2-\mathrm{OH})$ were found to be the most potent anti-microbial agent. It will be the topic of new research to substitute it with greener reagents, finding more effective anti-microbial agents.

\section{Acknowledgment}

The authors are highly thankful to Shree D.K.V. arts and science college, Jamnagar, for providing the best research opportunities. Special thanks are devoted to "National Facility for Drug Discovery Complex (NFDD), CoE, Department of Chemistry, Saurashtra University, Rajkot for data analysis facility.

\section{Experimental}

\subsection{Materials}

Chemicals and solvents were purchased from Sigma-Aldrich Chemical Co., Merck chemical, Finar, and Spectrochem Ltd. The entire chemicals were used without further purification. Thin-layer 
chromatography was accomplished on $0.2 \mathrm{~mm}$ precoated plates of Silica gel G60 F254 (Merck). Visualization was made under UV light (254 and 365nm). IR spectra were recorded on an "IR Affinity1S spectrophotometer (Shimadzu)". ${ }^{1} \mathrm{H}(400 \mathrm{MHz})$ and ${ }^{13} \mathrm{C}(101.1 \mathrm{MHz}) \mathrm{NMR}$ spectra were recorded on a "Bruker AVANCE III spectrometer" in $\mathrm{CDCl}_{3} / \mathrm{DMSO}-d_{6}$. Chemical shifts are expressed in $\delta \mathrm{ppm}$ downfield from TMS. Mass spectra were determined by an auto-injector system on a "GC-MS (Agilent 7820A-5977B, Santa Clara, CA, USA) mass spectrometer". Melting points were measured in open capillaries and are uncorrected.

\subsection{Method of Synthesis}

\subsubsection{Procedure for the synthesis of 4-isopropylbenzohydrazide. (2)}

In $100 \mathrm{ml} \mathrm{RBF}$ (round bottom flask), 4-isopropylbenzoate (16 gm, $0.1 \mathrm{~mol}$ ) and hydrazine hydrate ( $3.2 \mathrm{gm}, 0.1 \mathrm{~mol}$ ) were added in methanol media, and the mixture was refluxed for 2 hours at $70^{\circ} \mathrm{C}$ temperature. The reaction mixture was poured onto crushed ice, and the solid separated was filtered, washed with ether, and dried under vacuum. The obtained final adduct was used directly in the next step without further purification.

Yield: $64 \%$; m.p. $180{ }^{\circ} \mathrm{C}$; IR $(\mathrm{KBr}) \mathrm{cm}^{-1}: 3250$ (Aromatic symmetrical stretching of N-H of amide), 3054 (Aromatic symmetrical stretching of $\mathrm{C}-\mathrm{H}), 2880$ (C-H asymmetrical stretching of isopropyl group), 1650 (Aromatic symmetrical stretching of $\mathrm{C}=\mathrm{O}$ of amide), 1520 (Aromatic ring $\mathrm{C}=\mathrm{C}$ asymmetrical stretching), 1015 (Aromatic ring, $\mathrm{C}-\mathrm{H}$ in plane deformation), 765 (C-H out of plane deformation of mono substituted benzene ring); ${ }^{1} \mathrm{H}$ NMR (400 MHz, $\left.\mathrm{CDCl}_{3}, \delta \mathrm{ppm}\right): 9.64(\mathrm{~d}, 1 \mathrm{H}), 7.89$ $(\mathrm{s}, 2 \mathrm{H}), 7.50(\mathrm{~s}, 2 \mathrm{H}), 5.0(\mathrm{~m}, 1 \mathrm{H}), 4.9(\mathrm{~s}, 2 \mathrm{H}), 1.20(\mathrm{~d}, 6 \mathrm{H}) ;{ }^{13} \mathrm{C} \mathrm{NMR}\left(101.1 \mathrm{MHz}, \mathrm{CDCl}_{3}, \delta \mathrm{ppm}\right)$ : $167.44,147.83,133.27,131.18(2 \mathrm{C}), 124.96(2 \mathrm{C}), 34.20,23.37(2 \mathrm{C})$.

\subsubsection{Procedure for the synthesis of the potassium salt of 4-isopropylbenzyl thiocarbamate. (3)}

In a sealed tube mixture of potassium hydroxide $(8.40 \mathrm{~g}, 0.15 \mathrm{~mol})$ and 4-isopropyl benzohydrazide $(17.8 \mathrm{~g}, 0.1 \mathrm{~mol})$ were mixed in methanol $(25 \mathrm{ml})$ and carbon disulfide $(11.4 \mathrm{~g}, 0.15 \mathrm{~mol})$ was added slowly. It was stirred for 12 hours, and after completion of the reaction, it was diluted with dry ether (diethyl ether: $200 \mathrm{ml}$ ). The separated solid was filtered, washed with ether, and dried using a vacuum dryer.

There is no need to purify and characterize the salt for further reaction as it was identified under the TLC spot at the base level.

\subsubsection{Procedure for the synthesis of 4-amino-5-(4-isopropylphenyl)-4H-1,2,4-triazole-3-thiol. (4)}

In a suspension of the potassium salt of intermediate $3(2.9 \mathrm{~g}, 0.1 \mathrm{~mol})$ and hydrazine hydrate $(1.0 \mathrm{ml}, 0.2 \mathrm{~mol})$ in methanol $(3 \mathrm{ml})$ was refluxed for 3 hours at $70{ }^{\circ} \mathrm{C}$ temperature. [observations: The reaction mixture's color was changed to green due to evolved hydrogen sulfide gas]. It formed a homogeneous solution diluted with cold water $(100 \mathrm{ml})$ and neutralized with glacial acetic acid. The separated white solid precipitated was filtered, washed with cold water, and crystallized from dioxane to obtain an analytically pure product.

Yield: $60 \%$; m.p. $190^{\circ} \mathrm{C}$; IR (KBr) cm $\mathrm{cm}^{-1}: 3054$ (Aromatic symmetrical stretching of C-H), 2880 (C-H asymmetrical stretching of isopropyl group), $1591(\mathrm{C}=\mathrm{N}$ stretching of triazole ring), 1525 (Aromatic ring $\mathrm{C}=\mathrm{C}$ asymmetrical stretching), 1342 (C-N stretching of triazole ring), 1280 (C-O-C asymmetrical stretching ), 1018 (N-N stretching of triazole ring), 1014 (Aromatic ring, $\mathrm{C}-\mathrm{H}$ in plane deformation), 780 (C-H out of plane deformation of mono substituted benzene ring), 680 (C-S-C stretching of thiadiazole); ${ }^{1} \mathrm{H} \mathrm{NMR}\left(400 \mathrm{MHz}, \mathrm{CDCl}_{3}, \delta \mathrm{ppm}\right): 13.05(\mathrm{~s}, 1 \mathrm{H}), 8.57(\mathrm{~s}, 2 \mathrm{H}), 7.51(\mathrm{~s}, 2 \mathrm{H})$, $5.66(\mathrm{~d}, 2 \mathrm{H}), 2.87(\mathrm{~m}, 1 \mathrm{H}), 1.20(\mathrm{~d}, 6 \mathrm{H}) ;{ }^{13} \mathrm{C} \mathrm{NMR}\left(101.1 \mathrm{MHz}, \mathrm{CDCl}_{3}, \delta \mathrm{ppm}\right): 165.07,159.14,149.54$, 129.95 (2C), 126.59 (2C), 126.54, 34.20, 23.37 (2C). 
4.2.4 General procedure for the synthesis of 3-(4-isopropylphenyl)-6-sbstitutedphenyl$[1,2,4]$ triazolo[3,4-b][1,3,4]thiadiazole. $(5 a-5 j)$

A substituted aromatic acid (1.56 g, $0.01 \mathrm{~mol})$ and 4-amino-5-(4-isopropylphenyl)-4H-1,2,4triazole-3-thiol (4) $(2.34 \mathrm{~g}, 0.01 \mathrm{~mol})$ was heated at $80^{\circ} \mathrm{C}$ temperature in $\mathrm{POCl}_{3}(7.5 \mathrm{ml})$ media for 10 hours. The completion of the reaction was monitored by TLC [Hexane (3): Ethyl acetate (7)]. The reaction mixture was then dumped onto crushed ice and stirred at 2 hours to obtain a final solid product. The separated solid was isolated by simple vacuum filtration and washed with hexane (twice).

All the series (5a-5j) compounds were synthesized according to the above-cited protocols, and spectroscopic techniques did structural confirmation.

\subsection{Analytical data and Physical data}

\subsubsection{3-(4-Isopropylphenyl)-6-methoxy-[1,2,4]triazolo[3,4-b][1,3,4]thiadiazole (5a)}

Yield: $68 \%$; mp: $250{ }^{\circ} \mathrm{C}$; IR $\left(\mathrm{cm}^{-1}\right)$ : 3055 (Aromatic symmetrical stretch of $\mathrm{C}-\mathrm{H}$ ), $2880(\mathrm{C}-\mathrm{H}$ asymmetrical stretch of isopropyl group), $1590(\mathrm{C}=\mathrm{N}$ stretch of triazole ring), 1525 (Aromatic ring $\mathrm{C}=\mathrm{C}$ asymmetrical stretch), 1343 (C-N stretch of triazole ring), 1280 (C-O-C asy stretch), 1018 (N-N stretch of triazole ring), 1015 (Aromatic ring, $\mathrm{C}-\mathrm{H}$ in plane deformation), 780 (C-H out of plane deformation of mono substituted benzene ring), 680 (C-S-C stretch of thiadiazole); ${ }^{1} \mathrm{H} \mathrm{NMR} \mathrm{(400} \mathrm{MHz,}$ DMSO-d 6 , $\delta$ ppm) 8.10-8.18 (2H, m), 7.90-7.98 (2H, m), 7.38-7.47 (2H, m), 7.04-7.12 (2H, m), 3.89 $(3 \mathrm{H}, \mathrm{s}), 2.98(1 \mathrm{H}, \mathrm{m}), 1.25(\mathrm{~d}, J=6.47 \mathrm{~Hz}, 6 \mathrm{H}) ;{ }^{13} \mathrm{C}$ NMR $\left(101 \mathrm{MHz}, \mathrm{DMSO}-\mathrm{d}_{6}, \delta \mathrm{ppm}\right) 161.91$, 159.34, 158.19, 152.76, 145.73, 129.04, 127.87, 127.55, 126.62, 125.48, 114.32, 55.39, 34.12, 24.47; MS: $\mathrm{m} / \mathrm{z}=350.43\left(\mathrm{M}^{+}\right)$; Elemental analysis of $\mathrm{C}_{19} \mathrm{H}_{18} \mathrm{~N}_{4} \mathrm{OS}$ : Calculated= $\mathrm{C}, 65.12 ; \mathrm{H}, 5.18 ; \mathrm{N}, 15.99$; and Experimental= C, 65.12; H, 5.18; N, 15.23.

\subsubsection{4-(3-(4-Isopropylphenyl)-[1,2,4]triazolo[3,4-b][1,3,4] thiadiazol-6-yl)benzene-1,3-diol (5b)}

Yield: $62 \%$; mp: $195{ }^{\circ} \mathrm{C}$; IR $\left(\mathrm{cm}^{-1}\right)$ : 3059 (Aromatic symmetrical stretch of C-H), 2887 (C-H asymmetrical stretch of isopropyl group), $1595(\mathrm{C}=\mathrm{N}$ stretch of triazole ring), 1525 (Aromatic ring $\mathrm{C}=\mathrm{C}$ asymmetrical stretch), 1343 (C-N stretch of triazole ring), 1288 (C-O-C asy stretch), 1014 (N-N stretch of triazole ring), 1014 (Aromatic ring, C-H in plane deformation), 765 (C-H out of plane deformation of mono substituted benzene ring), 682 (C-S-C stretch of thiadiazole); ${ }^{1} \mathrm{H}$ NMR (400 MHz, DMSO-d $6, \delta \mathrm{ppm}) 11.56(1 \mathrm{H}, \mathrm{s}), 9.70(1 \mathrm{H}, \mathrm{s}), 8.08-8.16(2 \mathrm{H}, \mathrm{m}), 7.74(\mathrm{~d}, J=8.42 \mathrm{~Hz}, 1 \mathrm{H}), 7.37-7.46$ $(2 \mathrm{H}, \mathrm{m}), 6.57(\mathrm{dd}, J=8.42 \mathrm{~Hz}, 1 \mathrm{H}), 6.34(\mathrm{~d}, J=2.10 \mathrm{~Hz}, 1 \mathrm{H}), 2.98(\mathrm{~m}, 1 \mathrm{H}), 1.25(\mathrm{~d}, J=6.57 \mathrm{~Hz}, 6 \mathrm{H})$; ${ }^{13} \mathrm{C}$ NMR (101 MHz, DMSO-d 6 , $\delta$ ppm) 162.15, 161.76, 159.34, 158.22, 15819, 145.73, 129.71, 129.04, 126.62, 125.48, 110.90, 110.84, 103.84, 34.12, 24.47; MS: $\mathrm{m} / \mathrm{z}=352.41\left(\mathrm{M}^{+}\right)$; Elemental analysis of $\mathrm{C}_{18} \mathrm{H}_{16} \mathrm{~N}_{4} \mathrm{O}_{2} \mathrm{~S}$ : Calculated $=\mathrm{C}, 65.35 ; \mathrm{H}, 4.58 ; \mathrm{N}, 15.90$; and Experimental $=\mathrm{C}, 61.66 ; \mathrm{H}, 4.74 ; \mathrm{N}, 15.37$.

\subsubsection{3-(4-Isopropylphenyl)-6-o-tolyl-[1,2,4]triazolo[3,4-b][1,3,4]thiadiazole (5c)}

Yield: $56 \%$; mp: $180{ }^{\circ} \mathrm{C}$; IR $\left(\mathrm{cm}^{-1}\right)$ : 3054 (Aromatic symmetrical stretch of $\left.\mathrm{C}-\mathrm{H}\right), 2885(\mathrm{C}-\mathrm{H}$ asymmetrical stretch of isopropyl group), $1590(\mathrm{C}=\mathrm{N}$ stretch of triazole ring), 1524 (Aromatic ring $\mathrm{C}=\mathrm{C}$ asymmetrical stretch), 1342 (C-N stretch of triazole ring), 1286 (C-O-C asy stretch), 1013 (N-N stretch of triazole ring), 1015 (Aromatic ring, C-H in plane deformation), 755 (C-H out of plane deformation of mono substituted benzene ring), 680 (C-S-C stretch of thiadiazole); ${ }^{1} \mathrm{H}$ NMR (400 MHz, DMSO-d $6, \delta p p m) ~ 8.07-8.16(2 \mathrm{H}, \mathrm{m}), 7.74(\mathrm{dd}, J=7.65 \mathrm{~Hz}, 1 \mathrm{H}), 7.36-7.54(5 \mathrm{H}, \mathrm{m}), 2.97(1 \mathrm{H}, \mathrm{m}), 1.25$ $(\mathrm{d}, J=6.45 \mathrm{~Hz}, 6 \mathrm{H}) ;{ }^{13} \mathrm{C}$ NMR (101 MHz, DMSO-d6, $\delta$ ppm) 161.19, 159.34, 158.19, 145.73, 135.00, $134.32,129.68,129.04,128.47,128.42,126.62,125.48,125.46,34.12,24.47,19.65 ; \mathrm{MS}: \mathrm{m} / \mathrm{z}=333.43$ $\left(\mathrm{M}^{+}\right)$; Elemental analysis of $\mathrm{C}_{19} \mathrm{H}_{18} \mathrm{~N}_{4} \mathrm{~S}$ : Calculated $=\mathrm{C}, 68.23 ; \mathrm{H}, 5.42 ; \mathrm{N}, 16.75$; and Experimental= C, 68.61; H, 5.21; N, 16.44 . 
Yield: $62 \%$; mp: $190{ }^{\circ} \mathrm{C}$; IR $\left(\mathrm{cm}^{-1}\right)$ : 3065 (Aromatic symmetrical stretch of $\mathrm{C}-\mathrm{H}$ ), $2875(\mathrm{C}-\mathrm{H}$ asymmetrical stretch of isopropyl group), $1580(\mathrm{C}=\mathrm{N}$ stretch of triazole ring), 1570 (Aromatic ring $\mathrm{C}=\mathrm{C}$ asymmetrical stretch), 1353 (C-N stretch of triazole ring), 1280 (C-O-C asy stretch), 1017 (N-N stretch of triazole ring), 1018 (Aromatic ring, $\mathrm{C}-\mathrm{H}$ in plane deformation), 766 (C-H out of plane deformation of mono substituted benzene ring), 680 (C-S-C stretch of thiadiazole); ${ }^{1} \mathrm{H} \mathrm{NMR} \mathrm{(400} \mathrm{MHz,}$

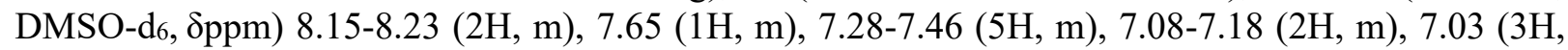
m), $2.96(\mathrm{~m}, 1 \mathrm{H}), 1.25(\mathrm{~d}, J=6.47 \mathrm{~Hz}, 6 \mathrm{H}) ;{ }^{13} \mathrm{C}$ NMR (101 MHz, DMSO-d $\left.6, \delta p p m\right) 159.34,158.19$, 156.84, 156.12, 151.83, 145.73, 136.49, 130.77, 129.52, 129.04, 126.62, 126.24, 125.48, 124.40, 119.71, 118.93, 112.63, 34.12, 24.47; MS: $\mathrm{m} / \mathrm{z}=412.50\left(\mathrm{M}^{+}\right)$; Elemental analysis of $\mathrm{C}_{24} \mathrm{H}_{20} \mathrm{~N}_{4} \mathrm{OS}$ : Calculated = C, 69.88; H, 4.89; N, 13.58; and Experimental = C, 69.34; H, 4.97; N, 13.89.

\subsubsection{6-(4-Bromophenyl)-3-(4-isopropylphenyl)-[1,2,4]triazolo[3,4-b][1,3,4]thiadiazole (5e)}

Yield: $65 \%$; mp: $230{ }^{\circ} \mathrm{C}$; IR $\left(\mathrm{cm}^{-1}\right)$ : 3055 (Aromatic symmetrical stretch of C-H), $2881(\mathrm{C}-\mathrm{H}$ asymmetrical stretch of isopropyl group), $1592(\mathrm{C}=\mathrm{N}$ stretch of triazole ring), 1526 (Aromatic ring $\mathrm{C}=\mathrm{C}$ asymmetrical stretch), 1346 (C-N stretch of triazole ring), 1281 (C-O-C asy stretch), 1013 (N-N stretch of triazole ring), 1010 (Aromatic ring, $\mathrm{C}-\mathrm{H}$ in plane deformation), 790 (C-H out of plane deformation of mono substituted benzene ring), 681 (C-S-C stretch of thiadiazole); ${ }^{1} \mathrm{H}$ NMR (400 MHz, DMSO-d $6, \delta p p m)$ 8.09-8.17 (2H, m), 7.84-7.92 (2H, m), 7.68-7.76 (2H, m), 7.39-7.48 (2H, m), 2.89$3.02(1 \mathrm{H}, \mathrm{m}), 1.25(\mathrm{~d}, J=6.47 \mathrm{~Hz}, 6 \mathrm{H}) ;{ }^{13} \mathrm{C} \mathrm{NMR}\left(101 \mathrm{MHz}, \mathrm{DMSO}-\mathrm{d}_{6}, \delta_{\mathrm{ppm}}\right) 159.34,158.19,152.76$, 145.73, 133.78, 131.05, 129.04, 128.37, 126.62, 125.48, 124.25, 34.12, 24.47; MS: $\mathrm{m} / \mathrm{z}=399.30\left(\mathrm{M}^{+}\right)$; Elemental analysis of $\mathrm{C}_{18} \mathrm{H}_{15} \mathrm{BrN}_{4} \mathrm{~S}$ : Calculated $=\mathrm{C}, 54.14 ; \mathrm{H}, 3.79 ; \mathrm{N}, 14.03$; and Experimental $=\mathrm{C}$, $54.23 ; \mathrm{H}, 3.79 ; \mathrm{N}, 14.03$.

\subsubsection{6-(4-Chlorophenyl)-3-(4-isopropylphenyl)-[1,2,4]triazolo[3,4-b][1,3,4]thiadiazole (5f)}

Yield: $54 \%$; mp: $245^{\circ} \mathrm{C}$; IR $\left(\mathrm{cm}^{-1}\right)$ : 3055 (Aromatic symmetrical stretch of C-H), $2880(\mathrm{C}-\mathrm{H}$ asymmetrical stretch of isopropyl group), $1595(\mathrm{C}=\mathrm{N}$ stretch of triazole ring), 1525 (Aromatic ring $\mathrm{C}=\mathrm{C}$ asymmetrical stretch), 1343 (C-N stretch of triazole ring), 1286 (C-O-C asy stretch), 1018 (N-N stretch of triazole ring), 1015 (Aromatic ring, $\mathrm{C}-\mathrm{H}$ in plane deformation), 770 (C-H out of plane deformation of mono substituted benzene ring), 682 (C-S-C stretch of thiadiazole); ${ }^{1} \mathrm{H}$ NMR (400 MHz, DMSO-d6, $\delta$ ppm) 8.09-8.17 (4H, m), 8.01-8.09 (2H, m), 7.38-7.47 (2H, m), $2.96(1 \mathrm{H}, \mathrm{m}), 1.25(\mathrm{~d}, J=$ $6.52 \mathrm{~Hz}, 6 \mathrm{H}) ;{ }^{13} \mathrm{C}$ NMR (101 MHz, DMSO-d6, $\left.\delta \mathrm{ppm}\right)$ 159.34, 158.19, 152.76, 145.73, 138.43, 133.80, 129.12, 129.04, 127.53, 126.62, 125.48, 34.12, 24.47; MS: $\mathrm{m} / \mathrm{z}=354.85\left(\mathrm{M}^{+}\right)$; Elemental analysis of $\mathrm{C}_{18} \mathrm{H}_{15} \mathrm{ClN}_{4} \mathrm{~S}$ : Calculated $=\mathrm{C}, 60.92 ; \mathrm{H}, 4.26 ; \mathrm{N}, 15.79 ;$ and Experimental $=\mathrm{C}, 61.33 ; \mathrm{H}, 4.39 ; \mathrm{N}, 15.93$.

\subsubsection{3-(4-Isopropylphenyl)-6-(4-nitrophenyl)-[1,2,4]triazolo[3,4-b][1,3,4]thiadiazole (5g)}

Yield: $45 \%$; mp: $240{ }^{\circ} \mathrm{C}$; IR $\left(\mathrm{cm}^{-1}\right)$ : 3055 (Aromatic symmetrical stretch of $\mathrm{C}-\mathrm{H}$ ), 2887 (C-H asymmetrical stretch of isopropyl group), $1590(\mathrm{C}=\mathrm{N}$ stretch of triazole ring), 1525 (Aromatic ring $\mathrm{C}=\mathrm{C}$ asymmetrical stretch), 1531 (N-O asymmetric stretch), 1345 (N-O asymmetric stretch) 1343 (C$\mathrm{N}$ stretch of triazole ring), 1288 (C-O-C asy stretch) 1014 (N-N stretch of triazole ring), 1012 (Aromatic ring, C-H in plane deformation), 770 (C-H out of plane deformation of mono substituted benzene ring), 682 (C-S-C stretch of thiadiazole); ${ }^{1} \mathrm{H}$ NMR (400 MHz, DMSO-d 6 , 8 ppm) 8.31-8.39 (2H, m), 8.10$8.21(4 \mathrm{H}, \mathrm{m}), 7.39-7.48(2 \mathrm{H}, \mathrm{m}), 2.96(1 \mathrm{H}, \mathrm{m}), 1.26(\mathrm{~d}, J=6.51 \mathrm{~Hz}, 6 \mathrm{H}) ;{ }^{13} \mathrm{C}$ NMR $(101 \mathrm{MHz}$, DMSO$\mathrm{d}_{6}$, Sppm) 159.34, 158.19, 152.76, 149.37, 145.73, 139.45, 129.04, 127.21, 126.62, 125.48, 123.86, 34.12, 24.47; MS: $\mathrm{m} / \mathrm{z}=365.40\left(\mathrm{M}^{+}\right)$; Elemental analysis of $\mathrm{C}_{18} \mathrm{H}_{15} \mathrm{~N}_{5} \mathrm{O}_{2} \mathrm{~S}$ : Calculated= C, 59.16; $\mathrm{H}$, 4.14; N, 19.17; and Experimental= C, 59.09; H, 4.64; N, 19.56. 
Yield: $53 \%$; mp: $210{ }^{\circ} \mathrm{C}$; IR $\left(\mathrm{cm}^{-1}\right)$ : 3059 (Aromatic symmetrical stretch of $\mathrm{C}-\mathrm{H}$ ), $2884(\mathrm{C}-\mathrm{H}$ asymmetrical stretch of isopropyl group), 1530 ( N-O asymmetric stretch), 1345 (N-O asymmetric stretch) $1595(\mathrm{C}=\mathrm{N}$ stretch of triazole ring), 1525 (Aromatic ring $\mathrm{C}=\mathrm{C}$ asymmetrical stretch), 1343 (C$\mathrm{N}$ stretch of triazole ring), 1288 (C-O-C asy stretch) 1019 (N-N stretch of triazole ring), 1014 (Aromatic ring, $\mathrm{C}-\mathrm{H}$ in plane deformation), 765 (C-H out of plane deformation of mono substituted benzene ring), 682 (C-S-C stretch of thiadiazole); ${ }^{1} \mathrm{H}$ NMR (400 MHz, DMSO-d $\left.6, \delta p p m\right) 8.67$ (t, $\left.J=2.24 \mathrm{~Hz}, 1 \mathrm{H}\right)$, $8.39(1 \mathrm{H}, \mathrm{m}), 8.26(1 \mathrm{H}, \mathrm{m}), 8.10-8.18(2 \mathrm{H}, \mathrm{m}), 7.81(\mathrm{t}, J=7.88 \mathrm{~Hz}, 1 \mathrm{H}), 7.39-7.48(2 \mathrm{H}, \mathrm{m}) 2.96(1 \mathrm{H}$, m), $1.26(\mathrm{~d}, J=6.51 \mathrm{~Hz}, 6 \mathrm{H}) ;{ }^{13} \mathrm{C}$ NMR (101 MHz, DMSO-d6, $\delta$ ppm) 159.34, 158.19, 151.83, 148.16, $145.73,137.79,131.69,129.64,129.04,126.62,125.48,123.39,121.53,34.12,24.47 ; \mathrm{MS}: \mathrm{m} / \mathrm{z}=$ $365.40\left(\mathrm{M}^{+}\right)$; Elemental analysis of $\mathrm{C}_{18} \mathrm{H}_{15} \mathrm{~N}_{5} \mathrm{O}_{2} \mathrm{~S}$ : Calculated= C, 59.16; H, 4.14; N, 19.17; and Experimental $=\mathrm{C}, 59.38 ; \mathrm{H}, 4.72 ; \mathrm{N}, 19.71$.

\subsubsection{2-(3-(4-Isopropylphenyl)-[1,2,4]triazolo[3,4-b][1,3,4]thiadiazol-6-yl)phenol (5i)}

Yield: $59 \%$; mp: $190{ }^{\circ} \mathrm{C}$; IR $\left(\mathrm{cm}^{-1}\right)$ : 3058 (Aromatic symmetrical stretch of $\mathrm{C}-\mathrm{H}$ ), 2887 (C-H asymmetrical stretch of isopropyl group), $1590(\mathrm{C}=\mathrm{N}$ stretch of triazole ring), 1520 (Aromatic ring $\mathrm{C}=\mathrm{C}$ asymmetrical stretch), 1343 (C-N stretch of triazole ring), 1288 (C-O-C asy stretch), 1012 (N-N stretch of triazole ring), 1014 (Aromatic ring, $\mathrm{C}-\mathrm{H}$ in plane deformation), 790 (C-H out of plane deformation of mono substituted benzene ring), 682 (C-S-C stretch of thiadiazole); ${ }^{1} \mathrm{H}$ NMR (400 MHz, DMSO-d $6, \delta p p m) 11.66(1 \mathrm{H}, \mathrm{s}), 8.08-8.16(2 \mathrm{H}, \mathrm{m}), 7.63(\mathrm{dd}, \mathrm{J}=7.85 \mathrm{~Hz}, 1 \mathrm{H}), 7.37-7.49$ (2H, m), 7.10 $(1 \mathrm{H}, \mathrm{m}), 6.98(\mathrm{dd}, J=7.82 \mathrm{~Hz}, 1 \mathrm{H}), 2.91-3.03(1 \mathrm{H}, \mathrm{m}), 1.26(\mathrm{~d}, J=6.45 \mathrm{~Hz}, 6 \mathrm{H}) ;{ }^{13} \mathrm{C}$ NMR $(101$ MHz, DMSO-d 6 , $\delta$ ppm) 162.15, 159.34, 158.19, 156.27, 145.73, 129.21, 129.04, 127.61, 127.61, 126.62, 125.48, 123.16, 119.44, 116.66, 34.12, 24.47; MS: $\mathrm{m} / \mathrm{z}=336.41\left(\mathrm{M}^{+}\right)$; Elemental analysis of $\mathrm{C}_{18} \mathrm{H}_{15} \mathrm{~N}_{5} \mathrm{O}_{2} \mathrm{~S}$ : Calculated $=\mathrm{C}, 64.26 ; \mathrm{H}, 4.79 ; \mathrm{N}, 16.65 ;$ and Experimental $=\mathrm{C}, 64.38 ; \mathrm{H}, 4.28 ; \mathrm{N}, 16.08$.

\subsubsection{6-(2-Chlorophenyl)-3-(4-isopropylphenyl)-[1,2,4]triazolo[3,4-b][1,3,4]thiadiazole (5j)}

Yield: $65 \%$; mp: $165^{\circ} \mathrm{C}$; IR $\left(\mathrm{cm}^{-1}\right)$ : 3059 (Aromatic symmetrical stretch of $\mathrm{C}-\mathrm{H}$ ), $2877(\mathrm{C}-\mathrm{H}$ asymmetrical stretch of isopropyl group), $1590(\mathrm{C}=\mathrm{N}$ stretch of triazole ring), 1525 (Aromatic ring $\mathrm{C}=\mathrm{C}$ asymmetrical stretch), 1343 (C-N stretch of triazole ring), 1288 (C-O-C asy stretch), 1017 (N-N stretch of triazole ring), 1014 (Aromatic ring, $\mathrm{C}-\mathrm{H}$ in plane deformation), 765 (C-H out of plane deformation of mono substituted benzene ring), 682 (C-S-C stretch of thiadiazole); ${ }^{1} \mathrm{H}$ NMR (400 MHz, DMSO-d6, $\delta$ ppm) $8.15(3 \mathrm{H}, \mathrm{m}), 7.57-7.68(3 \mathrm{H}, \mathrm{m}), 7.37-7.68(2 \mathrm{H}, \mathrm{m}), 2.96(1 \mathrm{H}, \mathrm{m}), 1.25(\mathrm{~d}, J=6.52$ $\mathrm{Hz}, 6 \mathrm{H}) ;{ }^{13} \mathrm{C}$ NMR (101 MHz, DMSO-d6, $\delta$ ppm) 163.59, 159.34, 158.19, 145.73, 132.39, 131.86, 130.86, 129.04, 127.59, 126.62, 126.03, 125.48, 34.12, 24.47; MS: m/z = $354.85\left(\mathrm{M}^{+}\right)$; Elemental analysis of $\mathrm{C}_{18} \mathrm{H}_{15} \mathrm{ClN}_{4} \mathrm{~S}$ : Calculated $=\mathrm{C}, 60.92 ; \mathrm{H}, 4.26 ; \mathrm{N}, 15.79$; and Experimental $=\mathrm{C}, 61.35 ; \mathrm{H}$, $4.69 ; \mathrm{N}, 15.79$.

\section{References}

1. Kerru N., Gummidi L., Maddila S., Gangu K., Jonnalagadda S. (2020) A Review on Recent Advances in Nitrogen-Containing Molecules and Their Biological Applications. Molecules, 25 (8) 1909-1950.

2. Gomtsyan A. (2012) Heterocycles in drugs and drug discovery. Chem Heterocycl Comp, 48, 710 .

3. Martins P., Jesus J., Santos S., Raposo L., Roma-Rodrigues C., Baptista P., Fernandes A. (2015) Heterocyclic Anticancer Compounds: Recent Advances and the Paradigm Shift towards the Use of Nanomedicine's Tool Box. Molecules, 20 (9) 16852-16891.

4. Jhaa A., Prasad K., Kulkarni A. (2009) Plant system: Nature's nano factory. Colloids and Surfaces B. Biointerfaces., 73 (2) 219-223. 
5. Georgios C., Dimitris T., Panagiotis D., Constantinos P., Vasiliki S., Panagiotis Z., Charalambos C. (2019) Synthesis and anti-cancer activity of novel 3,6-disubstituted 1,2,4-triazolo-[3,4-b]1,3,4-thiadiazole derivatives. Arab. J. Chem., 12 (8) 4784-4794.

6. Abdelrazek F., Gomha S., Abdel-aziz H., Farghaly M., Metz P., Abdel-Shafy A. (2020) Efficient synthesis and In Silico study of some novel pyrido[2,3-d][1,2,4]triazolo[4,3-a]pyrimidine derivatives, J. Heterocycl. Chem., 57 (4) 1759-1769.

7. Gomha S., Edress M., Muhammad Z., Gaber H., Amin M., Matar I. (2019) Synthesis Under Microwave Irradiation and Molecular Docking of Some Novel Bioactive Thiadiazoles. Mini-Rev. Med. Chem., 19 (5) 437-447.

8. Roberta J. (2017) Melander and Christian Melander, The Challenge of Overcoming Antibiotic Resistance: An Adjuvant Approach?. ACS Infectious Diseases, 3 (8) 559-563.

9. Reder-Christ K., Bendas G. (2011) Biosensor Applications in the Field of Antibiotic ResearchA Review of Recent Developments. Sensors, 11, 9450-9466.

10. Projan S., Shlaes D. (2004) Antibacterial drug discovery: Is it all downhill from here? Clin. Microbiol. Infect., 10, 18-22.

11. Annunziato G. (2019) Strategies to Overcome Antimicrobial Resistance (AMR) Making Use of Non-Essential Target Inhibitors: A Review. Int. J. Mol. Sci., 20 (23) 5844.

12. Varvaresou A., Tsantili-Kakoulidou A., Siatra-Papastaikoudi T., Tiligada E. (2000) Synthesis and biological evaluation of indole containing derivatives of thiosemicarbazide and their cyclic 1,2,4triazole and 1,3,4-thiadiazole analogs. Arzneimittel-Forschung., 50 (1) 48-54.

13. Prasad M., Lakshmi C., Katari N., Pal M. (2020) Lemon Juice as a Biocatalyst Under Ultrasound Irradiation: Synthesis and Pharmacological Evaluation of 2-amino 1,3,4-thiadiazoles. Anti-cancer Agents Med Chem., 20 (11) 1379-1386.

14. Alminderej F., Elganzory H., El-Bayaa M., Awad H., El-Sayed W. (2019) Synthesis and Cytotoxic Activity of New 1,3,4-Thiadiazole Thioglycosides and 1,2,3-Triazolyl-1,3,4Thiadiazole N-glycosides. Molecules, 24 (20) 3738.

15. Hu, Y., Li, C., Wang, X., Yang, Y., Zhu, H. (2014) 1,3,4-Thiadiazole: Synthesis, Reactions, and Applications in Medicinal, Agricultural, and Materials Chemistry, Chem. Rev., 114 (10) $5572-$ 5610.

16. Lidia L., Eliezer B. (2005) Bioisosterism: A Useful Strategy for Molecular Modification and Drug Design. Curr. Med. Chem., 12, 23-49.

17. Serban G., Stanasel O., Serban E., Bota S. (2018) 2-Amino-1,3,4-thiadiazole as a potential scaffold for promising anti-microbial agents. Drug Des Devel Ther., 12, 1545-1566.

18. Serban G. (2020) Synthetic Compounds with 2-Amino-1,3,4-Thiadiazole Moiety Against Viral Infections. Molecules, 25 (4) 942.

19. Liu Y., Zhang Y., Zhang J., Hu L., Han S. (2020) A copper-catalyzed approach for the synthesis of asymmetrical disubstituted 1,2,4-thiadiazoles via elemental sulfur-mediated decarboxylative redox cyclization. Tetrahedron Lett., 65, 152744.

20. Jain A., Sharma S., Vaidya A., Veerasamy R., Agrawal R. (2013) 1,3,4-Thiadiazole and Its Derivatives: A Review on Recent Progress in Biological Activities. Chem Biol Drug Des., 81 (5) 557-576.

21. Al-Masoudi I., Al-Soud Y., Al-Salihi N., Al-Masoudi N. (2006) 1,2,4-triazoles: synthetic approaches and pharmacological importance. Chem Heterocycl Compd., 42 (11) 1377-1403.

22. Maertens A. (2004) History of the development of azole derivatives. Clin Microbiol Infect., 10 (1) $1-10$.

23. Morigi R., Locatelli A., Leoni A., Rambaldi M. (2015) Recent Patents on Thiazole Derivatives Endowed with Antitumor Activity. Anticancer Drug Discov., 10 (3) 280-297.

24. Karabasanagouda Adhikari A., Shetty N. (2007) Synthesis and anti-microbial activities of some novel 1,2,4-triazolo[3,4-b]-1,3,4-thiadiazoles and 1,2,4-triazolo[3,4-b]-1,3,4-thiadiazines carrying thioalkyl and sulphonyl phenoxy moieties. Eur. J. Med. Chem., 42 (4) 521-529.

25. Bhalla M., Hitkari A., Gujrati V., Bhalla T., Shanker K. (1994) Benzopyran-2-one derivatives: antiinflammatory, analgesic and antiproteolytic agent. Eur. J. Med. Chem., 29 (9) 713-717. 
26. Kritsanida M., Mouroutsou A., Marakos P., Pouli N., Papakonstantinou-Garoufalias S., Pannecouque C., Witvrouw M., De Clercq E. (2002) Synthesis and antiviral activity evaluation of some new 6-substituted 3-(1-adamantyl)-1,2,4-triazolo[3,4-b][1,3,4]thiadiazoles. Farmaco, 57 253-257.

27. Chawla G., Kumar U., Bawa S., Kumar J. (2011) Syntheses and evaluation of anti-inflammatory, analgesic and ulcerogenic activities of 1,3,4-oxadiazole and 1,2,4-triazolo[3,4-b]-1,3,4thiadiazole derivatives. J Enzyme Inhib Med Chem., 27 658-65.

28. Chowrasia D., Karthikeyan C., Choure L., Sahabjada Gupta M., Arshad M., Trivedi P. (2017) Synthesis, characterization and anti-cancer activity of some fluorinated 3,6-diaryl[1,2,4]triazolo[3,4-b][1,3,4]thiadiazoles. Arab. J. Chem., 10 (2) S2424-S2428.

29. Zhang L., Zhao J., Zhang B., Lu T., Chen Y. (2018) Discovery of $[1,2,4]$ triazolo[3,4b] $[1,3,4]$ thiadiazole derivatives as novel, potent and selective c-Met kinase inhibitors: Synthesis, SAR study, and biological activity. Eur. J. Med. Chem., 150 809-816.

30. Pandit C., Pandya M., Jadeja Y., Gohel J., Kapadiya K. (2020) An efficient regioselective synthesis of N-alkylated purine-triazole analogues. Ind. J. Chem. Sect. B., 59B (8) 1225-1233.

31. Kapadiya K., Jadeja Y., Khunt R. (2018) Synthesis of Purine based Triazoles by Copper (I)Catalyzed Huisgen Azide-Alkyne Cycloaddition Reaction. J. Heterocycl. Chem., 55 (1) 199-208.

32. Wanja D., Mbuthia P., Robert M., Waruiru R., Bebora L., Ngowi H., Nyaga P. (2020) Antibiotic and Disinfectant Susceptibility Patterns of Bacteria Isolated from Farmed Fish in Kirinyaga County, Kenya. Int. J. Microbiol., 202088973388 pages.

33. Missaoui J., Saidane D., Mzoughi R., Minervini F. (2019) Fermented Seeds ("Zgougou") from Aleppo Pine as a Novel Source of Potentially Probiotic Lactic Acid Bacteria. Microorganisms, 7 (12) 709-731.

34. Nussbaumer-Pröll A., Knotzer S., Eberl S. (2019) Impact of erythrocytes on bacterial growth and anti-microbial activity of selected antibiotics. Eur J Clin Microbiol Infect Dis., 38 (3) 485-495.

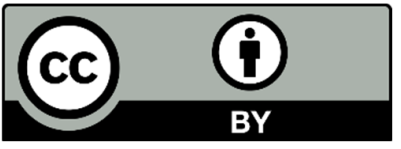

(C) 2021 by the authors; licensee Growing Science, Canada. This is an open access article distributed under the terms and conditions of the Creative Commons Attribution (CC-BY) license (http://creativecommons.org/licenses/by/4.0/). 